Commentary

\title{
Populist Postmodernism: When Cultural Critique of an Enlightenment Occupation Goes Viral
}

\author{
Jane B. Singer \\ Department of Journalism, City, University of London, London, EC1V OHB, UK; E-Mail: jane.singer.1@city.ac.uk
}

Submitted: 12 June 2019 | Accepted: 16 September 2019 | Published: 17 December 2019

\begin{abstract}
Journalism as an occupation has deep roots in the Enlightenment. The criticisms it faces, in contrast, reflect a populist permutation of Postmodernist critiques. This essay explores the implications for contemporary journalism, ending with suggestions for how practitioners might best respond.
\end{abstract}

\section{Keywords}

Democracy; Enlightenment; journalism; populism; postmodernism; truth

\section{Issue}

This commentary is part of the issue "Peripheral Actors in Journalism: Agents of Change in Journalism Culture and Practice" edited by Avery E. Holton (University of Utah, USA), Valerie Belair-Gagnon (University of Minnesota-Twin Cities, USA), and Oscar Westlund (Oslo Metropolitan University, Norway / Volda University College, Norway / University of Gothenburg, Sweden).

(C) 2019 by the author; licensee Cogitatio (Lisbon, Portugal). This article is licensed under a Creative Commons Attribution 4.0 International License (CC BY).

\section{Introduction}

In a fluid and immersive media environment, diverse actors occupy the same space and serve many of the same functions as the journalists who once were information linchpins. Digital and especially social media have blasted away restrictions on distribution, reach, and even impact. Everyone is talking at once, and anyone can join in. It all seems radically, sometimes frighteningly, new. Yet what we are experiencing can be viewed as a contemporary enactment of-and clash between-two inherently incompatible world views, neither of which is new at all.

\section{The Enlightenment}

The older of these emerged in the period we call the Enlightenment. Extending the ideas of a scientific revolution that gathered steam through the 17th century, Enlightenment philosophers and like-minded writers and thinkers hit their stride in the early 18th century across much of Europe. Hallmarks of what was at the time a seismic shift in social and intellectual conventions seem very familiar 300 years on.
Take the rise of coffeehouses in thriving and rapidly growing cities such as London. As today, these were places for conversation along with caffeine. Upriver in Oxford, such trendy meeting places were known as "penny universities"; that nominal admission charge brought access to news, some of it printed in early newspapers or newsletters and some of it communicated by "runners" who went from coffeehouse to coffeehouse announcing the latest developments. The conversationalists were an eclectic group, from all levels of societyquite unusual in a social world that placed great importance on class and economic status (Boulton, 2011). The result was not only an explosion of news and views (and no doubt of rampant misinformation and disinformation, too) but also a nascent media ecology in which sharing information was integral to its consumption. Indeed, sharing was-then as now-rather the whole point and certainly the key to enjoyable engagement with the news of the day, as those formerly on the periphery of the information whirl became increasingly central to its circulation.

Where London had its coffeehouses, Paris had its salons. A bit more literary in tone and less egalitarian 
in composition - though far more welcoming to women, who commonly served as hosts - the salons also were settings to debate the ideas of the day. Those ideas ranged from then-radical formulations of what have become core democratic principles, such as Voltaire's outspoken defence of civil liberties, to emerging ideas about the ability of intelligent but otherwise "ordinary" people to understand the world, epitomised by Denis Diderot's encyclopaedic compendia.

The emphasis in these cacophonous but convivial places was on reasoned argument, rational thought, and an open exchange of ideas in which many citizens might engage. Participants did not represent all social classes. But they did constitute a new cultural phenomenon: An engaged and informed public that blew holes in the old narrowly bounded knowledge circles of monarchy, clergy, and academy. Outsiders had become insiders.

And of course, the conversations in coffeehouses and salons, as well as their cousins around Western Europe and across the ocean in America, encompassed the scientific inventions and discoveries for which the Enlightenment is perhaps best known. Astronomers such as Copernicus, Galileo, and Kepler led Europe out of the Renaissance; inspired by their "scientific method" of close observation and meticulous measurement, others similarly uncomfortable with received wisdom unsupported by demonstrable evidence led her into the Enlightenment. The 17th century produced revolutionary work in mathematics, physics, chemistry, and biology from such giants as Isaac Newton and William Harvey in England, Christiaan Huygens in the Netherlands, and René Descartes in France, among many others. Dozens of seminal thinkers and innovators followed over the next 200 years and more, churning out a steady stream of ideas and inventions that caught the popular imagination. These children of the Enlightenment collectively created a world that had not only new tools but also an entirely new social and political structure.

What does all this have to do with journalism? A lot. The contemporary press in Britain-and America, its colony through most of the 18th century-is a direct descendant of coffeehouse culture, with its emphasis on timely news and gossip conveyed both verbally and through newsletters and other printed tracts. Similarly, the modern French press traces its more literary nature as a purveyor of social commentary to those salons. The story elsewhere was similar. Although printing predates the Enlightenment, this is the era when Western journalism in a form and with a mission we recognise today was born. The form was the newspaper; among others, the first editions of such still-publishing outlets as the Wiener Zeitung in Austria, the Gazzetta di Parma in Italy, and The Times in Britain appeared in the 18th century, as did dozens of other shorter-lived daily and weekly periodicals. And the mission was the timely dissemination of information about current affairs to the citizenry, who in turn added to its formulation through their own interaction and engagement.
Journalism as we know it, practice it, study it, and teach it is a product of the Enlightenment conceptually as well as literally. It rests on the belief that truth can be discovered, observed, and recorded. It also can be communicated to and understood by those citizens, who in turn can freely discuss and act on this information if they choose. Truth, in this view, is dichotomous-something is true or it is not-but it is not immutable; new information, in the form of scientific discoveries or fresh occurrences or simply more reliable reportage, can lead to new truth. Enlightenment thinkers were fine with subjectivity of opinion; indeed, the voices expressing diverse, contrarian, and even-notably in America and Francerevolutionary views grew steadily louder throughout the period. But subjectivity of truth was an oxymoron.

That remains the view of most journalists today. However, much they may acknowledge the difficulty of recognising, obtaining, and communicating "true facts," most journalists believe that reality exists-and that it can be observed and transcribed faithfully if not always fully. Journalism as an occupation was and remains a child of the Enlightenment, steeped in its philosophy that knowledge advances through the dogged gathering and careful recording of concrete evidence, and that society advances when such knowledge is clearly and accurately communicated to the public.

\section{Postmodernism...and Populism}

But needless to say, the world-intellectual no less than political and material-has moved on in 300 years. One major challenge to Enlightenment ideas and ideals, particularly though not exclusively about the nature of truth, has been the 20th century concept of Postmodernism.

Postmodernists emphasise that all human thought and action is relative to, and contingent on, a given individual's social position, power, value system, and more. Each person is socially conditioned, shaped by a vast variety of factors that in turn shape how he or she sees the world -and therefore how he or she arrives at and understands truth. Truth is not singular but rather plural and pluralistic. It is thus inherently subjective, quite the opposite of something that is universally obtainable or knowable if only we are good enough, skilful enough, diligent enough at pursuing it. Postmodern philosophers thus foreground relativism, positing that truth lies within the individual rather than "out there" in the world waiting to be discovered through rational and methodical thought.

But Postmodernism per se is an intellectual movement, a philosophical idea espoused mostly by...well, intellectuals and philosophers. For decades, it seemed relevant to most journalists mainly in the abstract. Ignoring it or perhaps indulging in a bit of eye-rolling was easy.

Far less easy is ignoring the ramifications of Postmodernism's transformation as it has escaped the ivory tower. Because freed of its academic rigour, Postmodernism has taken a decidedly populist turn. It has mutated into "post-truth." 
Journalists share the difficulties of living in a posttruth world with virtually all other purveyors of an Enlightenment-style approach to obtaining information and building knowledge. Experts right across the science and social science disciplines, and related occupations, are finding that the presentation of facts derived from observable evidence is being met with distrust if not derision. The Postmodern assertion that everyone has his or her own truth has become twisted into the populist assertion that everyone lies.

Moreover, everyone lies for a reason: to feather his or her nest one way or another. Why would journalists, the example nearest to our hearts, lie when their raison d'être ostensibly rests on telling the truth? For commercial reasons, obviously: to sell newspapers or inflate ratings or perhaps, for those a bit more attuned to media economics, simply to save their jobs in a hyper-competitive industry that seems to grow less financially secure by the day. But this is neither a new proposition nor an unfamiliar one (nor, to be fair, an entirely groundless one). Critical media scholars have been proclaiming for decades that journalists are in thrall to commercial interests. We should not be astounded that the point has morphed into a vituperative rationale for discrediting anything and everything that journalists produce.

For many years, scholars and other media critics also have been stressing the urgent need for journalists to encompass diverse perspectives not just in assessing truth but also in understanding what it even is. That view is enormously valuable, not least because a unitary truth renders unseen and unheard those who lack the means to challenge it. Journalists indeed pride themselves in their ability to offset that imbalance by "speaking truth to power," and well they should. After all, a central tenet of the Enlightenment view of truth was that it was open to debate by all, and that such debate would lead first to a more complete and reliable understanding of realityand ultimately to a better world.

But if every person's ideas deserve a hearing, then how are we to sort among them? We again should not be shocked-shocked!-to find that personal sentiment about a message or its sender has become of greater importance to many people than the actual merits of that message. For instance, do people trust acquaintances (whether actual besties or merely bots) and perceived opinion leaders who share content on social platforms more than they trust the original source (Turcotte, York, Irving, Scholl, \& Pingree, 2015)? Of course they do. If, as Postmodern theorists say, truth is a matter of individual assessment, then trust must logically rest on assessment of the individuals who claim to convey the truth. As populism has risen in societies that once nurtured Enlightenment ideas, trust in the media (and other institutions) has fallen-dramatically (Edelman, 2019). Journalism from traditional media outlets is today viewed with disbelief, if it is viewed at all, by large segments of the population.
Put such factors together, and journalists in a posttruth world find that they somehow need to counter charges that they are conveying neither an objective truth (the Enlightenment ideal) nor even a subjective one (the Postmodernist premise), but instead are putting out complete fabrications (the populist permutation of Postmodernism). They are struggling to restore trust not only in the belief that truth can be discovered and communicated, difficult though those tasks may be, but also trust in their own ability to discover and communicate it.

To summarise: Subjectivism and relativism are part of Postmodernist counter-claims to Enlightenment perspectives about what truth is and who is empowered to convey it. Those challenges have considerable merit. Yet when we see the philosophical ideas translated into action by people whom we are unlikely to view as fellow travellers, many of us are appalled. Journalists and academics alike see such radical scepticism from presumptively "peripheral" actors as dangerously ignorant. Yet many of the ideas espoused by contemporary populists on both sides of the Atlantic are essentially a mainstream articulation of points we ourselves have made about the shortcomings, especially relative to power and who gets to hold it, of Enlightenment perspectives on the nature of truth and who gets to tell it.

My point is not that Postmodern critiques of the Enlightenment-era enterprise of journalism are wrong. Often, they are spot-on, as well as useful, important, and indeed necessary. Besides, journalists make far too many mistakes of both fact and judgement to be paragons of Enlightenment virtue-or any other kind. Rather, my point is that what we are seeing in populist movements around the Western world-movements many of us find dismaying at best and horrifying at worst, as well as an existential threat to the free press that we treasure-are translations of the very arguments that elites have been making for decades. They may be simplistic or poorly informed or even ill-intentioned translations, and their enactment is often disturbing. But they are recognisably linked to well-rehearsed critiques of the nature of power in general and media power in particular.

\section{Can Journalists Adapt?}

We cannot know which of these diametrically opposite views of the nature of truth-and the composition of a good society-will prevail. In the meantime, I think journalists must continue their soul-searching about whether their occupation can change to fit the contemporary zeitgeist, and whether it should. I believe the answer to both questions is yes. But the task must be approached with considerable care because it is essential to identify which is the baby here and which the bathwater.

There are, I would suggest, a great many Enlightenment ideas that should not be allowed to drain away as the media scramble to safeguard their remaining economic capital and to regain their dwindling social capital. 
In my view, those include the ideas, or perhaps ideals, of truth as knowable and communicable to the best of our abilities; of discourse as most meaningful when it is open and inclusive; and of knowledge-building as perpetually in progress.

At a less abstract level, journalists have a lot of work to do. Over the quarter-century of the digital age, they have become reasonably good at changing how they gather information, interact with audiences and sources, and present stories, along with associated activities. I call these "habits of practice." They have been far less willing, or able, to change how they think about journalismtheir "habits of thought" (Singer, 2019). Some useful and achievable goals might include:

1) Conveying but not accepting without question other people's truths. The criticism that journalists give too much prominence to the views of elites-views that, let's just say, do not always serve the public interest as opposed to a personal or political one-is well-founded and readily documented. That practice leaves the media open to blatant and rampant manipulation of what is covered and the shape that coverage takes. Trapped by habits of thought in the form of judgements about what constitutes "news" and how to present it, journalists seem unable to stop snapping at bait that is deliberately dangled in front of them. They must acknowledge that a wider range of perspectives are "newsworthy," and make a more concerted effort to seek, find, and convey them. But they should not convey any of those perspectives uncritically. At the end of the day, the idea of truth as observable, verifiable, and dichotomous still comes closest to the mark. There are always alternative perspectives, and they should be heard. But pronouncements of presidential mouthpieces to the contrary, there are not alternative facts. Too often, journalists present alternative perspectives as facts simply because someone in authority puts them forward. That practice should stop soonest.

2) Dissociating "objectivity" from "truth." As Craft (2017) eloquently points out, objectivity is neither a synonym nor a substitute nor a stand-in for truth. Journalists, particularly in America, should stop claiming to be "objective," then digging themselves an even deeper hole to support that claim by presenting opposing views of unequal merit as equivalent. Philosophically, such practice doesn't hold up, and in the real world, journalists routinely are getting pounded for claiming to be objective when they are not. The link between objectivity and truth lies not in the message but rather in the method: how one goes about investigating truth, not about how one conveys it. This is the original concept pursued by Enlightenment scientists, in fact: Truth emerges through a due process of open-minded, honest investigationwhich is what journalists should foreground. That brings me to...

3) Communicating what goes into journalism, not just what comes out. Transparency is having a bit of a moment, and most journalists claim to like it. Yet most rarely bother with it. Much more could be done to communi- cate how and especially why news decisions are made. Fact-checkers, many of whom see themselves as offering not just a complement to traditional media formats but also a corrective to traditional media practices, illustrate one of many potential approaches. Fact-checkers excel at showing how they arrived at an adjudication about the veracity of a given statement, for instance through extensive links to supporting documentation. Traditional media could and should do much more of that sort of thing-and crucially, do so by making connections to content they did not create. A gazillion internal links to their own prior coverage can seem little more than an effort to drive traffic to old material that many readers did not believe the first time around. Diverse sources are inherently more credible. See above.

4) Facilitating the connections that audiences have always craved. News outlets are warming to this one, but they remain far behind social and search platforms in invoking the old coffeehouse buzz. Publishers moan loudly about Facebook, Google, and other tech giants using their content as a tool to siphon off advertising that attaches to that content. They moan, as well, about "fake news" and other forms of misinformation and disinformation, how widely it circulates, and how harmful it is. Both points have merit. But publishers tend to gloss over the core strength of these platforms, which is connecting people to other people-and doing it not just around personal memories or moments but also, and to a significant extent, around news. Why aren't media outlets doing more of that? Difficult though it can be to deflect the trolls, they are not even serious players in this game. They should be.

5) Taking advantage of abundance by embracing collaboration. Finally, another trend for which little green shoots are springing up: the trend toward collaborative work. Much of this now takes the form of working with otherwise competing news organisations on major stories, from international investigations such as the Panama Papers, to election coverage, to local datadriven projects. Working collaboratively with members of the public is harder, but it can be done, and with excellent results. The possibilities are amply demonstrated by newcomers such as Bellingcat, which routinely seeks help in verifying aerial photos or online videos, and by established organisations such as the BBC, which regularly solicits input from users with experience or expertise on a given topic. There are other ways to pursue this goal, as well; Robinson (2011), for instance, has written eloquently about the need to think about journalism as a process involving shared action distributed amongst multiple authors, rather than as a discrete end product. Such approaches help chip away at the distrust with which many regard news media of all stripes.

\section{Conclusion: Voices from within the Periphery}

Ultimately, citizens of any democracy must decide what they believe truth to be, how much they value it, and 
how they go about ensuring they get it. Journalists can and, I think, should do all the things just listed, without a huge amount of difficulty or investment of resources. Such things are not about chasing the pricy technological bells and whistles that Posetti (2018) labels "bright shiny things." Technology can be harnessed to help, but the points above are all about core journalistic goals, principles, and values-and inherently about journalism audiences who, at the end of the day, must make their choices.

It is said that we get the political leaders we deserve. We also get the news providers we deserve. That is the message high-quality outlets such as the Guardian are putting out, with some success: If you think what we do is valuable, then you need to support it. You need to support it by reading our content, by sharing it, and yes, by coming up with the dosh to pay for it one way or another.

To return to the loftier plain of philosophical discourse: We each must decide what we believe to be the best criteria for truth; how much we value that truth, whatever form it takes; and what actions we will take to ensure we get it. Turning away is an action, and it will generate a re-action, from the media as well as from others holding social power. If the reaction is not one we want, then it is our action that needs to change.

I have tried here to outline why I think Enlightenment ideas and ideals remain fundamentally valuable in our populist Postmodern times. Yes, those 300-year-old concepts come with dangers and shortcomings that are real and important. The Enlightenment, after all, led us to empire as well as empiricism. But it also led us to modern democracy, by proposing that we, the people, can know what is true; that we all have a right to such knowledge; and that we all need the freedom to act on the knowledge we have rightfully and rationally obtained. Journalists remain a vital link in the democratic chain. The journalist's view of democracy (Gans, 2003)? So be it. The role is worth protecting, and it is worth adapting habits of both practice and thought to safeguard.

\section{Conflict of Interests}

The author declares no conflict of interests.

\section{References}

Boulton, W. B. (2011). The amusements of old London. Cambridge: Cambridge University Press.

Craft, S. (2017). Distinguishing features: Reconsidering the link between journalism's professional status and ethics. Journalism \& Communication Monographs, 19(4), 260-301.

Edelman. (2019). Global Report: 2019 Edelman trust barometer. New York, NY, and Chicago, IL: Edelman. Retrieved from https://www.edelman.com/sites/ g/files/aatuss191/files/2019-03/2019_Edelman_ Trust_Barometer_Global_Report.pdf

Gans, H. (2003). Democracy and the news. Oxford: Oxford University Press.

Posetti, J. (2018). Time to step away from the "bright, shiny things"? Towards a sustainable model of journalism innovation in an era of perpetual change. Oxford: Reuters Institute for the Study of Journalism. Retrieved from https://reutersinstitute.politics.ox.ac. uk/sites/default/files/2018-11/Posetti_Towards_a_ Sustainable_model_of_Journalism_FINAL.pdf

Robinson, S. (2011). "Journalism as process": The organizational implications of participatory online news. Journalism and Communication Monographs, 13(3), 137-210.

Singer, J. B. (2019). Habits of practice, habits of thought. Journalism, 20(1), 135-139.

Turcotte, J., York, C., Irving, J., Scholl, R. M., \& Pingree, R. J. (2015). News recommendations from social media opinion leaders: Effects on media trust and information seeking. Journal of Computer-Mediated Communication, 20(5), 520-535.

\section{About the Author}

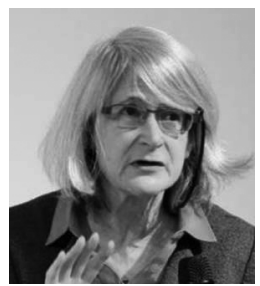

Jane B. Singer is Research Lead and Professor of Journalism Innovation at City, University of London. She previously held academic posts at the University of lowa and Colorado State University in the US, and served for three years as Johnston Press Chair in Digital Journalism at the University of Central Lancashire in the UK. A former print and online journalist, her research has traced the evolution of digital journalism since the mid-1990s, with a focus on journalists' changing roles, perceptions, norms, and practices. 